\title{
Mobile Positioning Data: Prediktor Produk Domestik Regional Bruto (PDRB) Pada Masa Pandemi
}

\author{
(Mobile Positioning Data: Predictor of Gross Regional Domestic Product during Pandemic) \\ Amanda Pratama Putra ${ }^{1}$, Heny Wulandari ${ }^{2}$ \\ ${ }^{1}$ Direktorat Pengembangan Metodologi Sensus dan Survei, Badan Pusat Statistik \\ ${ }^{2}$ Direktorat Statistik Keuangan, Teknologi Informasi, dan Pariwisata, Badan Pusat Statistik \\ Jl. Dr. Sutomo 6-8 Jakarta 10710 \\ E-mail: ${ }^{1}$ amanda.putra@bps.go.id
}

\begin{abstract}
ABSTRAK
Pandemi wabah virus corona (COVID-19) telah membatasi berbagai kegiatan, termasuk kegiatan pengumpulan data oleh BPS. Di sisi lain, pemerintah membutuhkan informasi yang dapat menggambarkan perkembangan dan situasi perekonomian secara cepat dan tepat agar dapat merumuskan kebijakan strategis ditengah kondisi pandemi. Penelitian ini memberikan sebuah pendekatan dalam memprediksi aktivitas ekonomi di Indonesia yang direpresentasikan oleh nilai Produk Domestik Regional Bruto (PDRB), yang didekatkan dari pengukuran nilai yang berbasis pada Mobile Positioning Data (MPD). Dengan menggunakan metode OLS dan analisis klaster, penelitian ini menunjukkan bahwa MPD dapat menjadi prediktor PDRB provinsi yang baik, terutama pada saat kondisi pandemi.
\end{abstract}

Kata kunci: COVID-19, mobile positioning data, aktivitas ekonomi, Indonesia

\begin{abstract}
The coronavirus pandemic (COVID-19) has hampered a variety of activities, including data collection activities by BPSStatistics Indonesia. On the other hand, in the midst of a pandemic, the government requires information that can accurately and swiftly characterize the development and economic condition in order to adopt strategic plans. This study provides an approach to predicting economic activity in Indonesia which is represented by the value of Gross Regional Domestic Product (GRDP) based on the Mobile Positioning Data (MPD). Using the OLS method and cluster analysis, this study shows that MPD can be a good predictor of provincial GRDP, especially during pandemic conditions.
\end{abstract}

Keywords: COVID-19, mobile positioning data, economic activity, Indonesia

\section{PENDAHULUAN}

Wuhan, sebuah kota di Republik Rakyat Tiongkok, mendadak menjadi perhatian dunia karena kemunculan kasus pertama wabah virus corona 2019 (COVID-19). Sejak pertama kali dilaporkan pada bulan Desember 2019, virus corona telah menyebar dan menginfeksi dengan cepat tidak hanya di Tiongkok tapi juga di seluruh penjuru dunia. Sampai dengan akhir Februari 2020, tercatat lebih dari 85 ribu kasus terkonfirmasi di 54 negara dan hampir 3 ribu kasus kematian (WHO, 2020). Peningkatan jumlah kasus yang signifikan dalam waktu singkat membuat Organisasi Kesehatan Dunia/World Health Organization (WHO) secara resmi mengumumkan wabah virus corona sebagai pandemi global pada Maret 2020.

Sebagai respons atas pernyataan tersebut, sejumlah negara telah mengambil tindakan agresif seperti menerapkan karantina wajib maupun lockdown berskala nasional untuk menekan dan mengontrol penyebaran wabah virus corona. Sementara di beberapa negara yang lain mengambil langkah sedikit longgar dengan memberlakukan pembatasan perjalanan. Di Indonesia sendiri, salah satu upaya pemerintah untuk mengurangi penyebaran wabah COVID-19 adalah dengan memberlakukan social distancing. Pemberlakuan social distancing ini diatur dalam Peraturan Pemerintah Nomor 21 Tahun 2020 tentang Pembatasan Sosial Berskala Besar (PSBB) pada 31 Maret 2020 yang meliputi peliburan sekolah dan tempat kerja, pembatasan kegiatan keagamaan, dan/atau kegiatan di tempat umum. Proses bekerja sendiri diganti dengan work from home untuk menjaga produktivitas/kinerja pekerja.

Adanya PSBB ini sedikit banyak berpengaruh terhadap Badan Pusat Statistik (BPS) sebagai lembaga penyedia data statistik, terutama terkait dengan pengumpulan data di lapangan. Di sisi lain, statistik yang dihasilkan oleh BPS sangat dibutuhkan oleh pemerintah maupun masyarakat umum. Salah satunya adalah angka Produk Domestik Bruto yang merupakan cerminan dari aktivitas ekonomi di suatu wilayah. Data 
mengenai aktivitas ekonomi sangat dibutuhkan oleh pemerintah dalam mengambil kebijakan untuk memitigasi dampak buruk pandemi terhadap perekonomian di tengah upaya menekan penyebaran wabah COVID-19.

Namun demikian, indikator ekonomi tersebut memiliki keterbatasan. Angka PDB pada umumnya diperoleh dengan cara konvensional, seperti melalui survei atau pengumpulan data sehingga tidak tersedia dalam waktu singkat (Beyer, Franco-Bedoya, \& Galdo, 2020). Padahal untuk dapat merumuskan kebijakan strategis secara cepat dan tepat ditengah kondisi pandemi, pemerintah membutuhkan data dan informasi yang dapat menggambarkan perkembangan dan situasi perekonomian yang tersedia dalam waktu relatif singkat. Keterbatasan ini mendorong eksplorasi sumber data alternatif yang dapat menyediakan informasi lebih cepat, dan dapat diolah dan dianalisis sedemikian rupa sehingga dapat digunakan sebagai proksi dari aktivitas ekonomi.

Penggunaan big data sebagai sumber data alternatif memunculkan peluang dan tantangan baru, khususnya penelitian baru di berbagai topik. Dalam beberapa tahun terakhir ini, berbagai penelitian yang menerapkan big data sebagai pendekatan baru untuk mengatasi keterbatasan data dan masalah pengukuran lainnya. Kovacs (2019) menyatakan bahwa penggunaan big data sebagai sumber data alternatif menjadi sangat penting karena big data dapat melengkapi dan menyempurnakan statistik resmi yang sudah ada atau yang sedang dalam tahap pengembangan. Selain itu, penggunaan big data juga dapat membantu memenuhi ketersediaan data dan dapat digunakan untuk menghasilkan statistik lainnya yang tersedia secara cepat dan terkini, salah satunya digunakan untuk memenuhi kebutuhan data dalam keadaan darurat, seperti bencana alam atau dalam hal ini pada masa pandemi.

Berangkat dari hal tersebut, penelitian ini bertujuan untuk menawarkan pendekatan baru dalam melihat aktivitas ekonomi dengan menggunakan big data. Lebih spesifik lagi, kami memfokuskan pada Mobile Positioning Data (MPD) untuk memprediksi PDRB sebagai indikator dari aktivitas ekonomi.

\section{KAJIAN LITERATUR}

Mobile Positioning Data (MPD) merupakan suatu dataset berskala besar mengenai catatan transaksi dan lokasi dari pelanggan dari operator seluler (Mobile Network Operator/MNO) yang diproses dan disimpan di dalam suatu sistem. Penggunaan MPD dipilih karena memiliki beberapa keunggulan (Ahas et al., 2010), yaitu:

1. Penggunaan telepon seluler tersebar luas dan populer, baik di negara maju dan berkembang. Saat ini, hampir seluruh masyarakat memiliki telepon seluler dan tidak terbatas pada kalangan tertentu saja;

2. Kecenderungan masyarakat untuk selalu membawa telepon seluler dan menjadikannya barang penting;

3. Data awal yang berbentuk digital sehingga bebas dari human error seperti keterbatasan ingatan responden atau kesalahan entri data; dan

4. Penggunaan MPD memungkinkan dalam mempelajari perpindahan penduduk dalam dimensi ruang dan waktu secara lebih tepat.

MPD sendiri telah banyak digunakan dalam berbagai konteks, seperti pariwisata (Raun, Ahas, \& Tiru, 2016), perencanaan transportasi (Liu, et al., 2014), dan pengukuran lalu lintas (Dong, et al., 2015). MPD juga telah digunakan untuk mendukung produksi statistik resmi di Indonesia, salah satu contohnya adalah studi tentang penggunaan MPD untuk memperkirakan arus komuter (Putra, Setyadi, Lestari, \& Esko, 2019).

Penelitian yang lainnya adalah yang dilakukan oleh Arhipova, et al. (2019) yang bertujuan untuk menganalisis aktivitas ekonomi di tingkat regional di Latvia berdasarkan data telepon seluler. Idenya adalah bahwa menginvestigasi data aktivitas tertentu dari telepon seluler dapat memberikan insight mengenai mobilitas penduduk di suatu wilayah. Dan mobilitas penduduk ini akan membentuk suatu pola sesuai dengan aktivitas ekonominya. Sebagai contoh, daerah pusat perekonomian cenderung tinggi aktivitas telepon selulernya di hari kerja, sebaliknya daerah tempat berlibur atau rekreasi cenderung tinggi aktivitas telepon selulernya di akhir pekan.

Arhipova, et al. (2019) menggunakan data aktivitas telepon seluler per orang yang dijumlahkan di area masing-masing base station dengan interval 15 menit. Data aktivitas yang digunakan meliputi jumlah panggilan keluar dan masuk, layanan pesan singkat (Short Messaging Service/SMS) yang terkirim dan diterima, dan juga jumlah pengguna unik. Dari penelitian tersebut, hipotesis yang menyatakan bahwa suatu wilayah dengan aktivitas telepon selular yang rendah akan memiliki aktivitas ekonomi yang rendah dibandingkan dengan wilayah lain dengan aktivitas telepon selular yang lebih tinggi tidak dapat ditolak. Dengan demikian dapat disimpulkan bahwa bahwa aktivitas telepon seluler memiliki hubungan yang 
signifikan secara statistik terhadap aktivitas ekonomi regional seperti PDRB. Oleh karena itu, dalam penelitian kami juga menggunakan hipotesis yang sama yaitu terdapat hubungan antara aktivitas penggunaan telepon seluler dengan PDRB di Indonesia.

\section{METODOLOGI}

\section{Data dan Sumber Data}

Penelitian ini menggabungkan penggunaan MPD sebagai sumber data alternatif dengan data Produk Domestik Regional Bruto (PDRB) sebagai statistik resmi dalam mengetahui kondisi ekonomi di suatu wilayah pada periode tertentu.

a) Mobile Positioning Data (MPD)

Mobile Positioning Data (MPD) dalam penelitian ini mengacu pada MPD pasif, yaitu data lokasi berskala besar pelanggan operator seluler yang diproses dan disimpan secara otomatis dalam sistem operator setiap kali ponsel seseorang berinteraksi dengan jaringan seluler (Altin, Tiru, Saluveer, \& Puura, 2015). Data untuk studi ini dikumpulkan dari Telkomsel, sebuah operator seluler terbesar di Indonesia, lebih khusus pada sampel dataset kombinasi data CDR (Call Detail Record), data Location Based Advertising/Signaling (LBA/LBS), dan data UPCC (Unified Policy and Charging Controller).

Data CDR adalah data lokasi pelanggan yang terekam ketika melakukan aktivitas pengiriman atau penerimaan pesan Short Message Service (SMS) dan aktivitas panggilan. Data ini terdiri dari nomor identitas penelepon dan orang yang dihubungi secara anonim namun konsisten, jenis aktivitas seperti panggilan atau pesan teks, durasi panggilan, timestamp pada saat panggilan, dan pengidentifikasi menara seluler tempat pengguna yang terhubung ke lokasi geografis menara seluler. Data Location Based Advertising/Signaling (LBA/LBS) adalah data lokasi pelanggan yang terekam ketika melakukan segala aktivitas yang melibatkan jaringan seluler, seperti akses internet, updating lokasi wilayah, pencarian jaringan saat ponsel dihidupkan, atau aktivitas lainnya. Aktivitas SMS dan panggilan dalam CDR juga termasuk di dalam LBA/LBS ini. Sedangkan data UPCC adalah data yang dihasilkan dari aktivitas broadband internet pelanggan.

Untuk penelitian ini, kami menggunakan dataset berupa sampel MPD yang terdiri dari jumlah pelanggan yang terdeteksi. Data tersebut dikumpulkan berdasarkan hari mulai dari tanggal 1 Januari 2020 hingga 30 April 2020 di setiap provinsi di Indonesia. Data ini mencakup kondisi sebelum pandemi global yang dinyatakan oleh WHO (bulan Januari dan Februari 2020) dan pada masa pandemi COVID-19 (Maret dan April 2020). Dalam penelitian ini, sebanyak 5 persen data diambil secara acak dengan distribusi proporsional mengikuti distribusi populasi, kemudian didistribusikan secara merata mengikuti hari dan wilayah administrasi. Jumlah pengguna unik dihitung selama waktu tertentu untuk memberikan informasi tentang aktivitas rata-rata di wilayah yang terekam oleh BTS (Arhipova, et al., 2019).

b) Produk Domestik Regional Bruto

Pada dasarnya PDRB adalah nilai tambah yang dihasilkan oleh seluruh unit usaha (sektor) dalam suatu daerah tertentu, atau jumlah nilai barang dan jasa akhir yang dihasilkan oleh seluruh unit ekonomi. Data PDRB yang digunakan adalah data PDRB triwulanan yang dihitung berdasarkan pendekatan harga konstan (Atas Dasar Harga Konstan/ADHK) untuk setiap provinsi di Indonesia. Data ini digunakan sebagai indikator pengukuran aktivitas ekonomi di tingkat regional. Hal ini karena Indonesia terdiri dari 34 provinsi dengan berbagai kontribusi sektor ekonomi yang berbeda terhadap PDRBnya. Penggunaan harga konstan ditujukan untuk mengatasi pengaruh faktor inflasi. Dalam studi ini, kami menggunakan data PDRB triwulanan, yaitu triwulan 12020 (Januari - Maret) dan triwulan 22020 (April - Juni). Data PDRB merupakan data sasaran yang akan digunakan sebagai benchmark untuk menilai kemampuan MPD sebagai proksi yang menggambarkan kondisi perekonomian. Untuk proses pemodelan, nilai PDRB ditransformasikan ke dalam bentuk logaritma natural (ln).

\section{Metode Analisis}

MPD merupakan data passive positioning yang dapat memberikan informasi mengenai mobilitas pelanggan secara real-time sehingga layak digunakan sebagai alternatif pendekatan aktivitas ekonomi. Banyaknya pelanggan unik yang terdeteksi melalui MPD juga secara tidak langsung dapat menggambarkan kepadatan penduduk yang merupakan bagian yang tidak terpisahkan dari kegiatan ekonomi. Studi ini terdiri dari beberapa tahapan, sebagai berikut:

1. Menghitung jumlah total pelanggan yang dikumpulkan berdasarkan hari dan provinsi. 
2. Mengelompokkan (clustering) provinsi menggunakan metode k-means menjadi dua klaster berdasarkan pola unik pelanggan harian. Median jumlah pelanggan dinormalisasi dengan normalisasi Z-score masing-masing provinsi.

3. Menghitung jumlah pelanggan unik dari langkah 1 menjadi pelanggan rata-rata yang dikumpulkan menurut kuartal dan provinsi. Hasilnya, terdapat 68 record yang terdiri dari 34 record nilai median jumlah pelanggan unik per hari yang mewakili kondisi pada triwulan 12020 dan 34 record lainnya untuk triwulan 2 2020. Sebelum digunakan pada tahap pemodelan, nilai tersebut dinormalisasi menggunakan metode normalisasi minimum-maksimun untuk menutupi nilai sebenarnya (terkait dengan kerahasiaan data dari operator seluler).

4. Mengestimasi dengan metode regresi Ordinary Least Square (OLS) untuk memprediksi PDRB menggunakan nilai MPD yang sudah dihitung pada langkah ketiga untuk setiap klaster provinsi dengan mengikuti model berikut:

$\ln p d r b=\beta_{0}+\beta_{1} \times$ cluster $_{2}+\beta_{2} \times$ median subs $+\beta_{3} \times$ median subs $\times$ cluster $_{2}+\varepsilon$

keterangan:

ln $p d r b=$ PDRB triwulanan ADHK dalam bentuk logaritma natural cluster $=$ klaster provinsi

median subs = nilai median jumlah pelanggan unik

5. Mengevaluasi model regresi dengan memeriksa signifikansi model dan masing-masing variabel.

\section{HASIL DAN PEMBAHASAN}

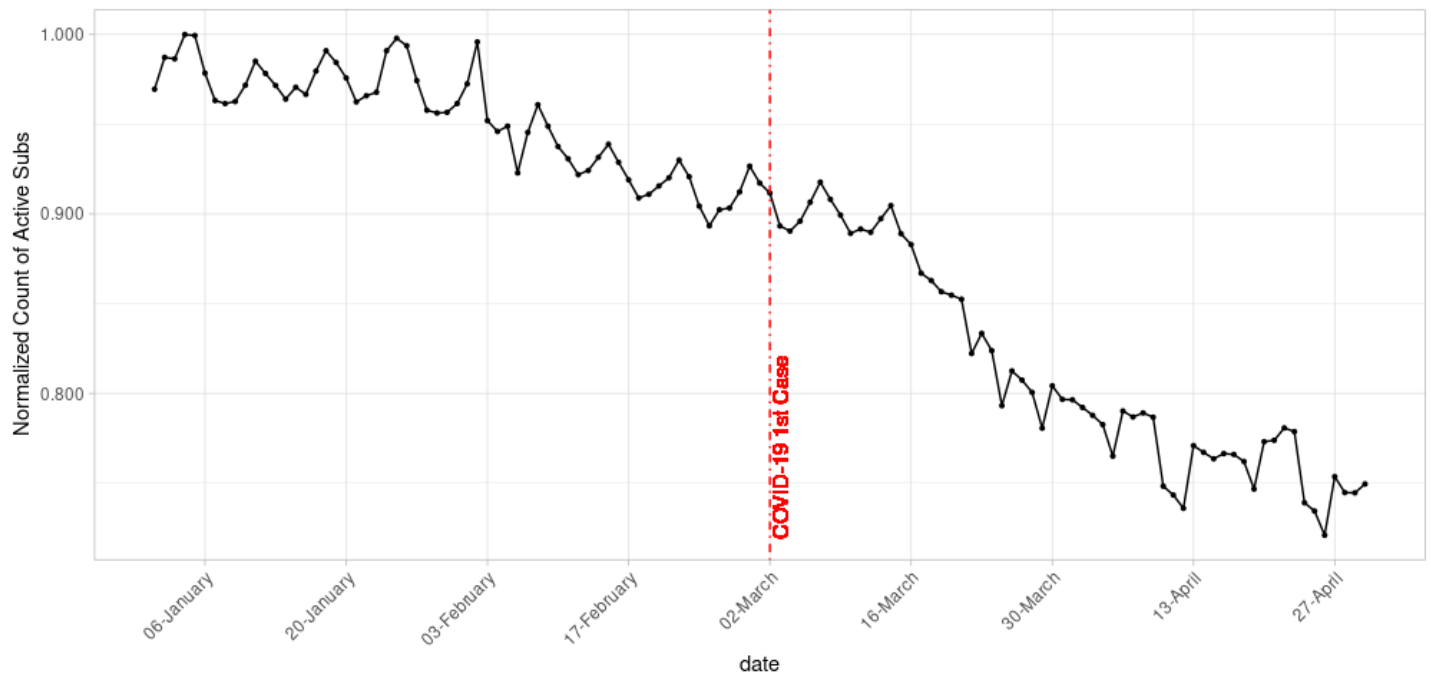

Gambar 1. Jumlah Pelanggan Unik yang Dinormalisasi

Berdasarkan data yang telah diolah, jumlah pelanggan unik mulai dari awal tahun 2020 sampai dengan awal Februari 2020 tetap stabil (masa sebelum pandemi), kemudian mulai mengalami penurunan secara bertahap hingga kasus pertama virus corona dilaporkan di Indonesia pada awal Maret 2020. Dalam kurun waktu singkat, jumlah pengguna unik menurun drastis ketika kebijakan Pembatasan Sosial Berskala Besar (PSBB) diterapkan untuk mengurangi penyebaran COVID-19 pada pertengahan Maret 2020, seperti yang terlihat pada Gambar 1. Penurunan terus berlanjut hingga mencapai hampir 20 persen pada April 2020. 


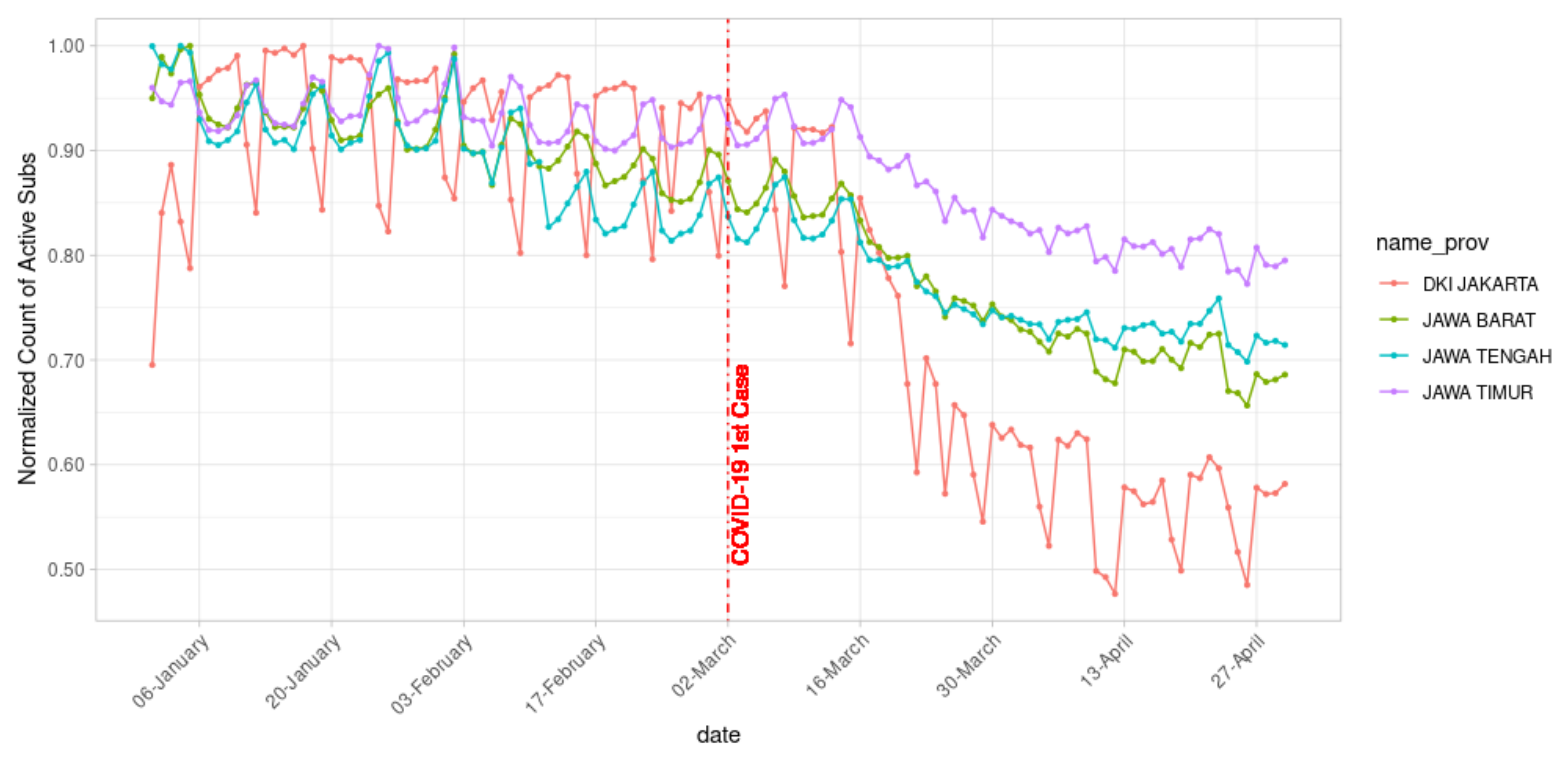

Gambar 2. Jumlah Pelanggan Unik yang Dinormalisasi di Beberapa Provinsi

Jika dilihat pola jumlah pelanggan unik di beberapa provinsi seperti yang disajikan pada Gambar 2, terlihat jelas bahwa penurunan jumlah pelanggan unik di Provinsi DKI Jakarta lebih curam dibandingkan dengan provinsi besar lainnya seperti di Jawa Barat, Jawa Tengah, dan Jawa Timur. Hal ini mengindikasikan bahwa pandemi COVID-19 memberikan dampak ekonomi yang lebih besar pada daerah yang berfungsi sebagai sentra kegiatan ekonomi dibandingkan di daerah-daerah lainnya. Dari grafik ini juga ditemukan indikasi musiman (seasonality) berdasarkan hari kerja. Sebagai contoh, rata-rata jumlah pelanggan unik di DKI Jakarta pada akhir pekan lebih rendah dibandingkan pada hari kerja. Namun pola sebaliknya terjadi di Jawa Barat, di mana jumlah pelanggan unik lebih tinggi pada akhir pekan dibandingkan pada hari kerja.

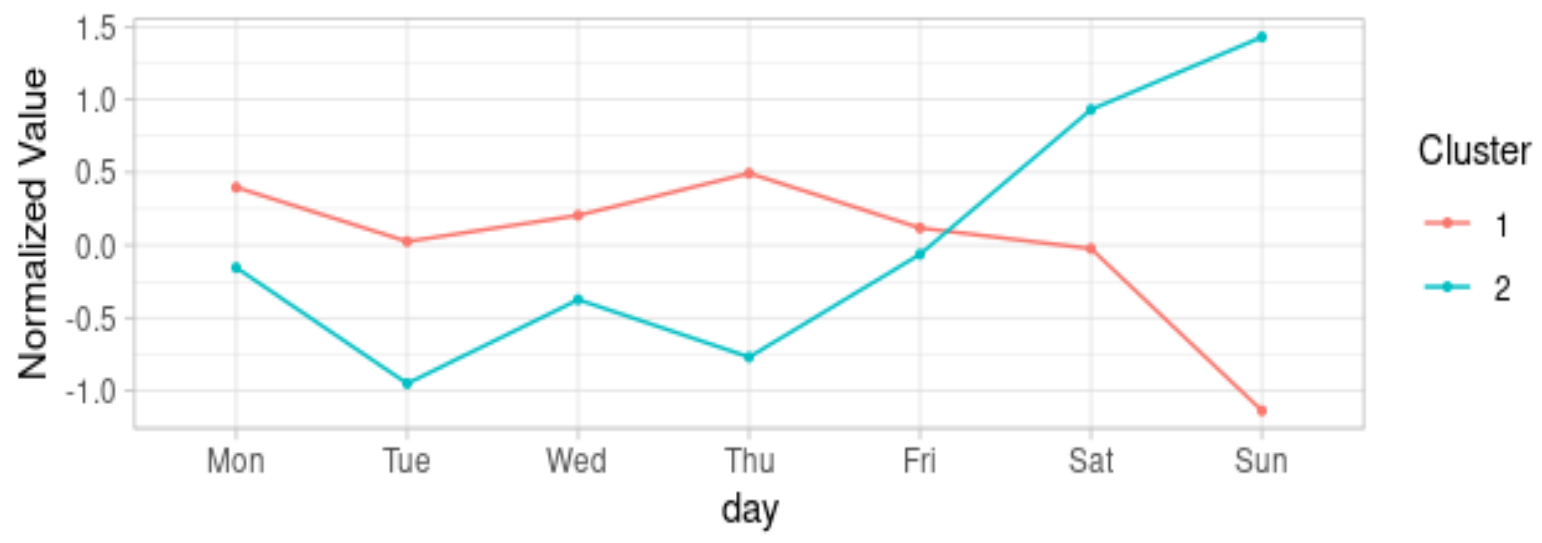

Gambar 3. Klaster Provinsi menurut Aktivitas Pelanggan

Analisis klaster dilakukan untuk mengelompokkan provinsi dengan pola MPD yang sama berdasarkan aktivitas ekonomi menurut data agregat harian. Analisis klaster menggunakan metode K-means (MacQueen, 1967) untuk mencari kesamaan pola harian tiap provinsi. Berdasarkan indeks siluet (Rousseeuw, 1987) untuk mencari jumlah klaster yang optimal, dibentuk 2 klaster yang masing-masing kelompok terdiri dari 20 provinsi dan 14 provinsi. Perbandingan pola harian pada masing-masing klaster disajikan pada Gambar 3. Klaster 1 mengelompokkan provinsi dengan aktivitas pelanggan yang lebih tinggi pada hari kerja sedangkan klaster 2 mengelompokkan provinsi dengan aktivitas pelanggan yang lebih tinggi pada akhir pekan. Hal ini menunjukkan bahwa klaster 1 merupakan kelompok provinsi dengan aktivitas kerja yang tinggi sehingga pola mobilitasnya cenderung lebih aktif pada hari kerja.

Dalam penelitian ini, model regresi menjelaskan hubungan antara MPD dan PDRB ADHK dengan mempertimbangkan klaster provinsi. Hasil penelitian menunjukkan bahwa jumlah pelanggan dari MPD memiliki hubungan yang signifikan dengan PDRB ADHK dengan koefisien determinasi sebesar 0,7976. 
Dengan kata lain, model tersebut menjelaskan 79,76 persen variabilitas PDRB. Selain itu, residual model memenuhi asumsi normalitas yang dikonfirmasi oleh uji Shapiro-wilk (Saphiro \& Wilk, 1965) dengan p-value sebesar 0.2181 (gagal tolak $\mathrm{H}_{0}$ ) yang berarti bahwa residual mengikuti distribusi normal.

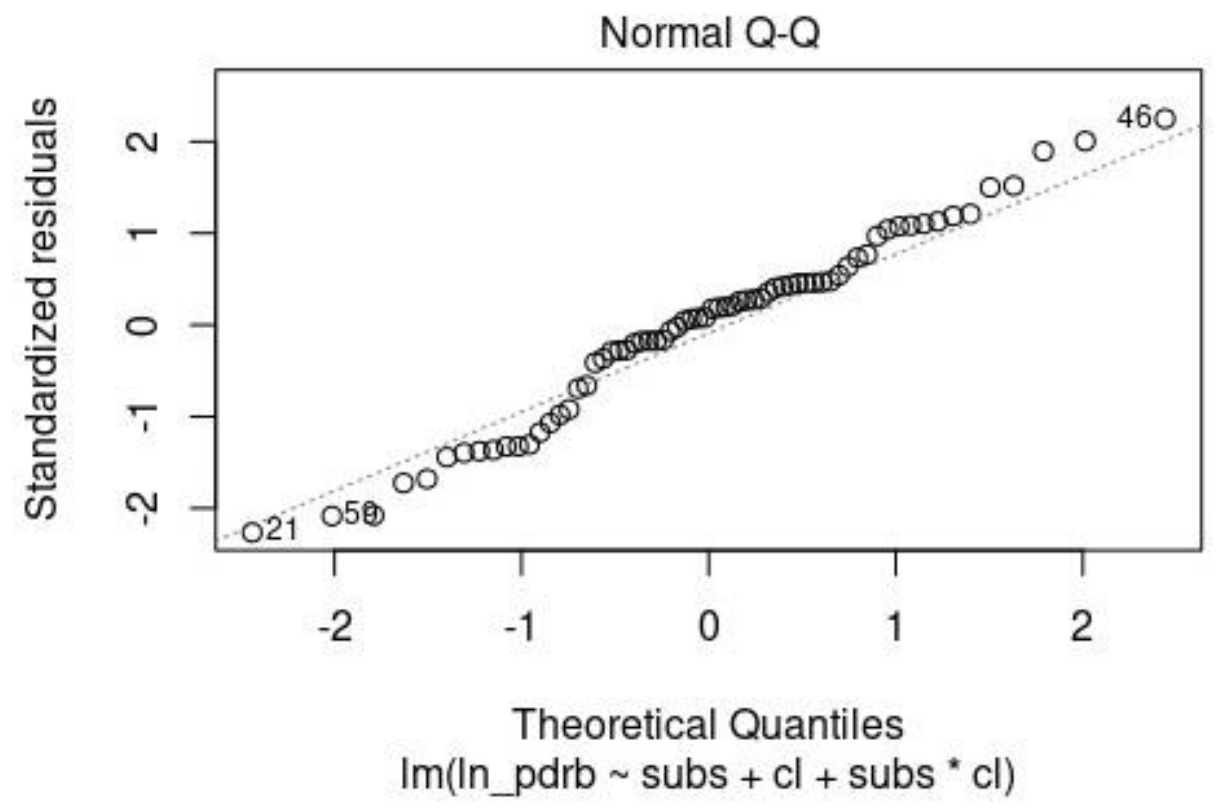

Gambar 4. Uji Normalitas

Tabel 1. Hasil Regresi PDRB ADHK dan MPD

\begin{tabular}{|c|c|c|}
\hline Parameter Regresi & Koefisien & p-value \\
\hline Intercept $\left(\beta_{0}\right)$ & 16.4097 & $<.0001 * * *$ \\
\hline Cluster $_{2}\left(\beta_{1}\right)$ & 0.4797 & $.0058 * *$ \\
\hline Median subs $\left(\beta_{2}\right)$ & 12.0977 & $<.0001 * * *$ \\
\hline Median subs $*$ Cluster $_{2}\left(\beta_{3}\right)$ & -8.5714 & $<.0001 * * *$ \\
\hline & 89 , p-value: <2.2e-16 & \\
\hline
\end{tabular}

Dari tabel di atas terlihat bahwa jumlah pelanggan secara signifikan berhubungan dengan PDRB ADHK dengan p-value $<0,05$. Secara keseluruhan, model juga dapat dikatakan baik, ditunjukkan dengan p-value dari uji $\mathrm{F}$ yang jauh lebih kecil dari 5 persen. Klaster provinsi yang merepresentasikan perbedaan pola aktivitas sehari-hari juga mempengaruhi hubungan antara jumlah pelanggan dengan PDRB. Hal ini terlihat dari parameter $\beta_{3}$ yang juga signifikan.

\section{KESIMPULAN DAN SARAN}

Pandemi COVID-19 telah menyebabkan penurunan aktivitas ekonomi di Indonesia yang tercermin dari penurunan jumlah aktivitas pelanggan yang terekam di MPD. Studi ini menemukan hubungan yang signifikan antara jumlah pelanggan operator seluler dengan PDRB ADHK di 34 provinsi di Indonesia selama periode triwulan 1 dan triwulan 2 tahun 2020. Selain itu, analisis klaster yang digunakan untuk mengelompokkan 34 provinsi ke dalam dua klaster berdasarkan pola MPD harian memiliki peran penting dalam model regresi. Hal ini terlihat dari koefisien variabel interaksi yang juga signifikan dalam model. Berdasarkan penelitian ini, dapat disimpulkan bahwa MPD dapat menjadi prediktor yang baik dalam melihat pola kegiatan ekonomi daerah di Indonesia, khususnya ketika terjadi perubahan ekonomi akibat perubahan pola mobilitas manusia.

Meskipun demikian, kami sadari bahwa penelitian ini masih banyak kekurangan. Penggunaan OLS dalam model ini mengasumsikan bahwa perilaku data antar provinsi sama dalam berbagai kurun waktu. Penelitian selanjutnya diharapkan dapat menggunakan jumlah sampel yang lebih besar, periode pengamatan yang lebih lama, dan juga metode yang lebih baik agar dapat mengatasi kelemahan dalam penelitian ini. 


\section{DAFTAR PUSTAKA}

Ahas, Rein., Silm, Siiri., Järv, Olle., Saluveer, Erki., \& Tiru, Margus. (2010). Using Mobile Positioning Data to Model Locations Meaningful to Users of Mobile Phones. Journal of Urban Technology. 17. 3-27. 10.1080/10630731003597306.

Altin, L., Tiru, M., Saluveer, E., \& Puura, A. (2015). Using Passive Mobile Positioning Data in Tourism and Population Statistics. the New Techniques and Technologies for Statistics 2015 proceedings. Brussel: Eurostat.

Arhipova, I., Berzins, G., Brekis, E., Binde, J., \& Opmanis, M. (2019). Mobile Phone Data Statistics as Proxy Indicator for Regional Economic Activity Assessment. International Conference on Finance, Economics, Management and IT Business (FEMIB), 27-36.

Beyer, R., Franco-Bedoya, S., \& Galdo, V. (2020). Examining the economic impact of COVID-19 in India through daily electricity consumption and nighttime light intensity. World Development.

Dong, H., Wu, M., Ding, X., Chu, L., Jia, L., Qin, Y., \& Zhou, X. (2015). Traffic zone division based on big data from mobile phone cellular base stations. Transportation Research,58, 278-291.

Kovacs, K. (2019). Big data for official statistics: The UN perspective. Regional workshop on the use of mobile phone data.

Liu, F., Janssens, D., Cui, J. X., Wang, Y. P., Wets, G., \& Cools, M. (2014). Building a validation measure for activity-based transportation models based on mobile phone data. Expert Systems with Applications, 41(14), 6174-6189.

MacQueen, J. (1967). Some methods for classification and analysis of multivariate observations. Proceedings of 5th Berkeley Symposium on Mathematical Statistics and Probability (pp. 281-297). University of California Press.

Putra, A. P., Setyadi, I. A., Lestari, T. K., \& Esko, S. (2019). Measuring Commuting Statistics in Indonesia Using Mobile Positioning Data. Asia Pacific Economic Statistik Week. Bangkok: UNESCAP.

Raun, J., Ahas, R., \& Tiru, M. (2016). Measuring tourism destinations using mobil tracking data. Tourism Management, 57, 202-212.

Rousseeuw, P. J. (1987). Silhouettes: A Graphical Aid to the Interpretation and Validation of Cluster Analysis. Computational and Applied Mathematics, 53-65.

Shapiro, S. S., \& Wilk, M. B. (1965). An Analysis of Variance Test for Normality (Complete Samples). Biometrika, 591-611.

WHO. (2020). Coronavirus disease 2019 (COVID-19) Situation Report - 40. Geneva: WHO. 